\title{
China's Brands, China's Brand development strategies and Corporate Brand Communications in China
}

\author{
Professor John M.T. Balmer \\ and \\ Dr Weifeng Chen \\ Brunel Business School \\ Brunel University \\ London UB8 3PH \\ England \\ UK \\ $7^{\text {th }}$ May, 2015
}

THIS IS A PRE-PUBLICATION OF AN ARTICLE WHICH WILL APPEAR IN THE JOURNAL OF BRAND MANAGEMENT VOL. 22 NO. pp. 1-19.

(provisional citation)

Balmer, J.M.T. and Chen, W> (2015) China's Brands, China's Brand development strategies and corporate brand communications in China, Journal of Brand Management, Vol. 22. pp. 1-19.

\section{Abstract}

The main contributions of the article include (a) the identification of different modes of brand development with five dimensions being identified: home-grown, corporate heritage, acquisition, association, joint-venture, alliance) and (b) the introduction of a distinct Chinese corporate brand total communications framework (this comprises primary, secondary, tertiary, family, gaunxi, and party [communist party] communications). This article identifies seven reasons why there has been a growth of interest in brands in China and also provides an overview of the main themes contained in the literature on China's brands and brand management in China. Taking an historical perspective, it examines the use and significance of brands in China; identifies similarities with the importance accorded to China and the situation which existed in Great Britain during the industrial revolution. It notes the factors which have led to the exponential growth of interest in brands in China.

KEY WORDS: China, Brands, Corporate Brands, Corporate Brand Communications 


\section{INTRODUCTION}

In the 1980s when China's so-called bamboo curtain was drawn after the reforms of China's Premier Deng Xiamping not only did the western capitalist notion receive the imprimatur of the Chinese State, but tellingly, capitalism was enthusiastically embraced by many Chinese individuals.

Significantly, these reformation in thought exposed-and exposed very quickly-the Chinese to whole, fascinating, world of brands. In many meaningful ways, Chinese citizens' primary exposure to the west and to western capitalism mainly, came in the form of brands.

China's new mercantile and entrepreneurial class developed new, home-grown, brands whilst managers of established brands such as Air China and Haier increasingly viewed these organisations in branding and, moreover, in corporate branding term . As such they appear to have adopted the fundamentals of corporate brand management (Balmer 1995; 2001; 2010, 2012) along with a corporate brand logic (2013).There was also an appreciation that China had more established heritage and corporate heritage brands. Tellingly, these heritage brands were given an official status by the Chinese state as Laizhous. Many of these corporate heritage brands not only remained true to their core purposes and which, today, remain meaningful: TongRenTang - the traditional Chinese Medicine corporate brand dating back to the $17^{\text {th }}$ Century- is an exemplar (Balmer and Chen 2015).

\section{BRAND CHINA IN CONTEXT}

In both contemporary and historical contexts, China (both the term and the brand) was and is -redolent with multiple connotations in branding terms. Arguably, since time immemorial China has been one of the most famous, celebrated and ubiquitous brands on the world stage: it is a place brand is a brand that is without parallel.

The above being said, China means many different things to different people and in different contexts. Whilst some of China's brand associations are complementary, some are controversial, - even counterintuitive.

For instance, the very notion of China arouses powerful emotions among the Chinese. For some, China is not one country but two: the Republic of China (Formosa) and the People's Republic of China. Strictly speaking, the Chinese character denoting China 
中国 literally translates as "The Middle Kingdom". As such, for those in the west it seems incongruous that two republican Chinese states have a nomenclature which categorises them as a Kingdom.

Moreover, China the brand is not so much as a country but is, moreover, a peerless and millennia-old Civilisation. However, it is a civilisation that is informed by numerous ethnicities and in terms of contemporary China as a communist State is, paradoxically, a country informed by a capitalist ethos. This being said, sight should not be lost of, what is arguably, China's most powerful brand: the Communist Party of China, It is still not uncommon to see posters extoling thrift, filial devotion, Chinese Civilisation and the Communist Party. The latter epitomised by the mantra: "The Communist Party is good, the people are happy" (The Economist 2014b).

It has long been recognised that understanding China-as well as reading the Chinese mind-can be highly problematic. As such, this has given rise to a category of scholar/official -the sinologist-who is a connoisseur of all things Chinese; is highly adroit in their dealings and communication with the Chinese. At one time many sinologists were to be found within the UK's Foreign and Commonwealth Office. Arguably, the most celebrated of all sinologists was an Englishman: the celebrated Cambridge University Don Joseph Needham CH (李约瑟);

What is incontrovertible is the fact that the $21^{\text {st }}$ century is destined to witness the renaissance of China hegemony in a number of fields: and one of these surely will be in the branding domain. This should come as no surprise considering the inexorable growth and strength, of the Chinese economy; the country's rapid industrialisation; the rise of a wealthy-and aspirational-middle class and, importantly, the size of the Chinese population: around a fifth of the world's population are Chinese.

Moreover, China's various appetites and needs are voracious and no more are this so than in the branding realm. As such, China is not only developing home grown brands; developing global brands but also not only accessing but also acquiring emblematic western brands including Volvo, Gieves and Hawkes, London Taxis, Pirelli, House of Fraser and Weetabix.

Importantly, sight should not be lost that the People's Republic of China is in branding terms qualitatively different from the China of twenty years ago owing to its rise as a significant economic and military power. Today, China is the $2^{\text {nd }}$ biggest economy and is probably destined to become the largest economy: a very different situation from twenty years ago (The Economist 2014a). Its economic might is pervasive and can be seen in Asia, Australasia and, more especially, in Africa. It manifests itself in Europe 
and Italy is a case in point with a former Italian Prime Minister, Romano Prodi, wistfully noting that "Italian industrial policy is now made in Beijing." Certainly, Chinese companies are following a state diktat to acquire high quality foreign brands. Chinese companies now own the Italian yacht builder brand Ferretti and Ferragamo the celebrated fashion house The Economist (2015).

However, its soft power is comparatively weak. Significantly, the Chinese state has also attempted to burnish the "soft power" of the China brand via cultural activities in an attempt to complement-as with as ameliorate some of the contentious aspects ofChina's "hard" power. For the sake of balance, mention should be made of Taiwan (the Republic of China) which (in country of origin branding terms) is celebrated for its brands: several have a global presence.

Erroneously, China is sometimes characterised as being devoid of well-known brands. To us, this seems curious and reflects a somewhat narrow conceptualisation and comprehension of China's brands. For us, China does have iconic brands and because they are linked to the state, to parties or to religious philosophies and movements, or because of their status as place brands does not mean that their status are diminished. Consider the following:

- The Communist Party of China

- Mao Tse Tung and Jung Gio Ping (personality brands)

- The Peoples' Liberation Army

- Confucianism

- Daoism

- Beijing

- Hong Kong

- Macao

- Shanghai

- Xi'an

- Shangri-La (a region in South West China)

- Cathay Pacific Airways

Consider, too, China's domestic corporate brands: China Mobile-being a case in point as one of the People's Republic largest corporate brands. It is a corporate brand which-has a customer-base of around 600 million customers (The Economist, 2011d, 2011e). It is still, for instance, difficult for foreigners to obtain a credit card in China and it was only quite recently-in February 2012-that Citibank became the first Western bank to be allowed to offer credit cards under its own brand name. (The 
Economist, 2012c). In international contexts, mention can be made of Triangle brand which is a notable player in the global tyre market as is Haier in the white goods sector. Also of note is the well-documented association between Lenovo and IBM; and China's acquisition of iconic automotive marques including Volvo (purchased by Geely); MG (purchased by SAIC); and London Taxis (purchased by Geely). Those of us who have visited China - or teach Chinese students - will also be acutely aware of Chinese attachment to the Baidu and Alibaba online brands/search engines.

Overseas brands enjoy a high presence and respect in China. For instance, China is one of its fastest growing markets for the U.S.,-based Walmart supermarket chain: the brand has more than 350 stores in the People's Republic and employs almost 100,000 staff (The Economist, 2011b). Luxury brands also fare well, such as the iconic British corporate brand Burberry. Indeed, Burberry is China's prime market (The Economist, 2011a).

\section{The Chinese Diaspora "Diasporation"}

No discussion of China's brands can neglect the importance of China's Diaspora which can be found in very many parts of the world and which often make up a sizeable proportion of certain countries (Singapore, Malaysia); provinces (British Columbia) and cities (New York, London).

The effect of what we call Diasporation can be considerable in terms of creating a global market for (in this case) Chinese brands for use by the Chinese community but also in terms in creating awareness and interest in Chinese brands in overseas markets.

China Town: an ubiquitous global place brand

Consider, for instance, in tourism contexts, the popularity and widespread occurrence of the "China Town Generic Brand" in many countries including Bangkok, London, Manchester, New York, Sydney, Vancouver, to name but a few. China town is not so much a place but one brand in many places.

\section{THE ASCENDANCY OF CHINA AND ITS' BRANDS: EXPLANATIONS}

An understanding as to why China's economy has grown and interest in branding has developed is attributable to a number of factors: many of which are interrelated. These can be detailed as follows (see figure 1): 


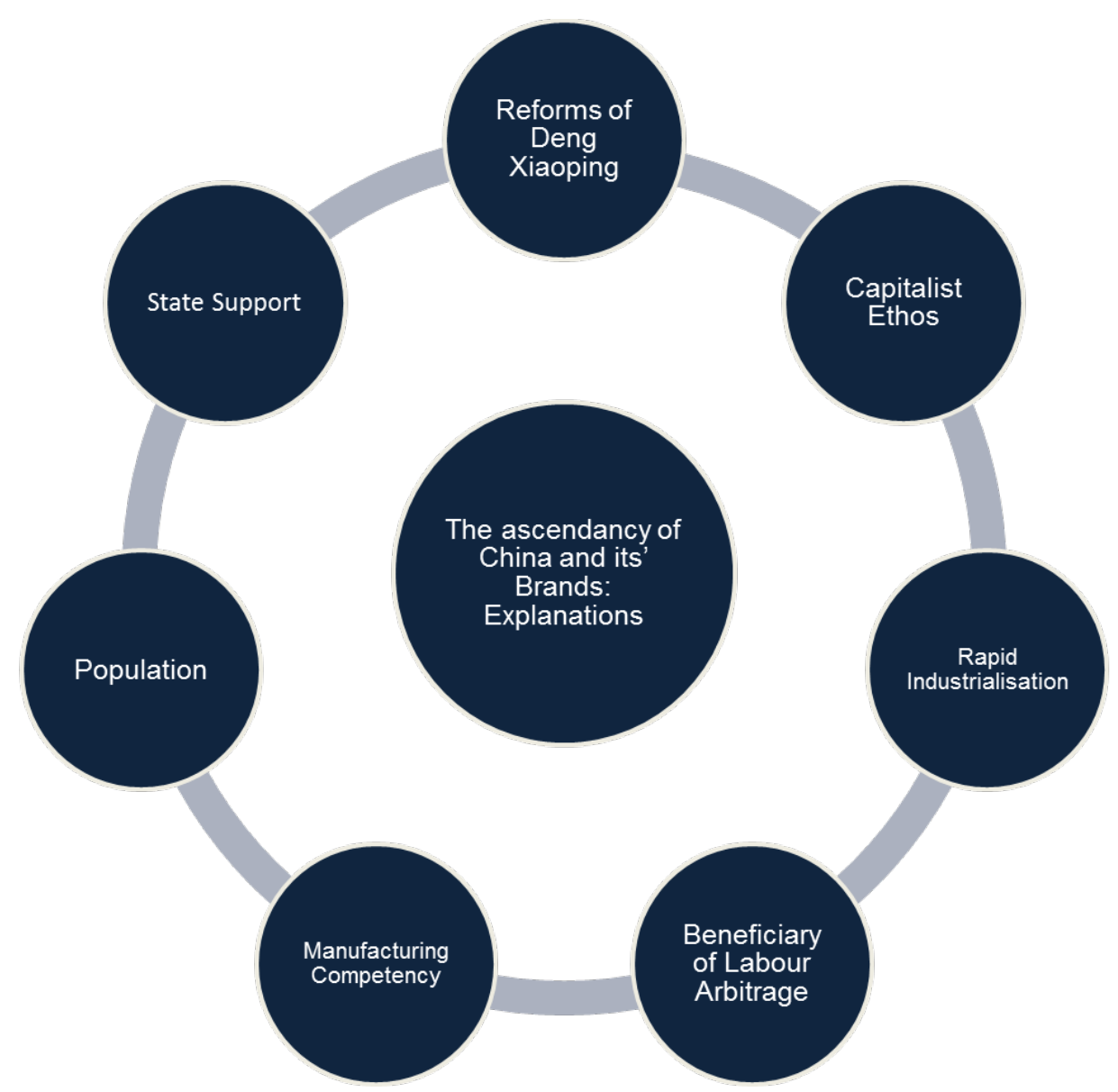

Figure 1 The ascendancy of China and its' brands: explanations

1. Reforms of Deng Xiaoping: Reforms brought about Deng Xiamping in the 1980s not only moulded the polity and economy of China but in marketing and branding terms also heralded profound change. It was, for instance, Deng Xiaoping who uttered the words: "To become rich is glorious." (The Economist, 2008b).

2. Capitalist Ethos: China is a leading exemplar of state capitalism (The Economist, 2011c) and this system has allowed new brands to emerge and older brands to grow

3. Population: Today China has a largely urban population: in 1980 the population was overwhelmingly agrarian in character, (The Economist, 2012b) and, arguably, this resulted in a greater disposition for consumers to have greater branding foci. 
4. Rapid Industrialisation: Manufacturing has enjoyed a phenomenal growth over the last few decades and this, in part, explains the rise of B to B branding and the establishment on new "home grown" brands.

5. Manufacturing Competency: China has now taken over the mantle from Japan as the country where many products-especially cheap products-areas manufactured (The Economist, 2010a) and understandably new brands have emerged as a consequence.

6. Beneficiary of Labour arbitrage: China has benefitted from Labour arbitrage-the -outsourcing production and capitalising on lower wages overseas-is, now, a well-known phenomenon in the industrialised west and, in many, China's B to B brands has been a beneficiary of these strategic moves.

7. State Support: $80 \%$ of the market capitalisation of China's stockmarket is taken up by state-controlled companies. It is an incontrovertible fact that state support has, in many instances, been a key factor vis-à-vis the development of certain Chinese brands (The Economist, 2011d)

\section{THREATS TO CHINA AND ITS BRANDS}

For the sake of balance, it is possible to identify a number of "threats" to China's status and threats to its brands. (One of these threats relates to issues of trust and the rule of law but, increasingly China seeks to protect its own intellectual property rights including its brands and this has resulted in a greater adherence within China to "the rule of law". (The Economist, 2008a). The threats facing China are detailed below (also see figure 2).

Figure 2 Threats to China and its brands

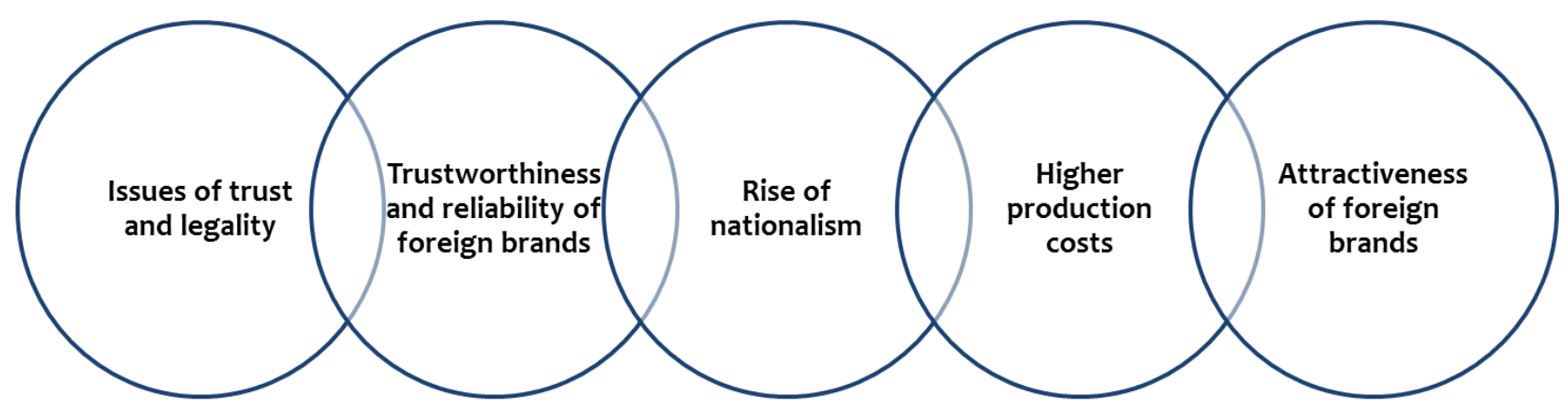

Higher production costs: As wage levels increase and as the standard of living rises along with the expectations vis-à-vis employment, the cost of manufacturing products in China is becoming less attractive to western brands. 
Attractiveness of foreign brands: increased wealth means that Chinese covet branded - and increasingly more expensive and more expensive foreign brands as a consequence.

Trustworthiness and reliability of foreign brands: High profile food contamination scares have undermined confidence in native food and beverage brands. (Thus allowing overseas brands such as Nestle and Arla to capatalise on this weakness) (The Economist, 2011b ,2012a).

Issues of trust and legality: intellectual property theft from the west and a failure to honour foreign patents and copyrights within China has been damaging and this may have hindered inward investment, joint agreements, and the introduction of brands within China.

Rise of nationalism: Importantly, not everyone in China in enamoured with the capitalism and with the western democratic ethic. Not surprisingly, the massive changes within the Middle Kingdom have given rise to nationalism and have caused foreign brands to be shunned. The above is epitomised by such groups as the fenqing ('angry youth') which are scornful of the notion of universal rights and discount political and economic liberalism and western attitudes. Taking an historical perspective, such attitudes are redolent of earlier political movements in China such as the Boxers and anti-western Boxer Uprising of 1900 (The Economist, 2011d, 2011e).

\section{THE CHINESE BRANDING RENAISSANCE: WHAT IS IT? WHAT OF IT?}

We label the current growth of interest in and importance accorded to brands in China a renaissance since China was, for several millennia, a civilisation which was known and coveted for its prowess in innovation, business acumen and manufacturing capability. As such, it has an unparalleled status as a country of origin brand. Whereas, today (although this positioning is rapidly changing) its products tend to be considered "low" quality, for many years anything carrying the China name denoted the highest quality. As such, China enjoyed considerable respect. A legacy of this is the well-known English aphorism: "Damned clever those Chinese"

As the English scholar Joseph Needham CH noted (Winchester 2008) right up until the $15^{\text {th }}$ century, Imperial China had an unmatched provenance in terms of its scientific innovations. China was a nation of innumerable "firsts": the first to introduce the magnetic compass; the first to build the first chain drive and the first to introduce printing etc. Yet, as Needham chronicled, China had forgotten its provenance in this area. Of course, it is highly ironic that it took an Englishmen to remind China of their achievements. Needham also famously noted, China, has years-failed to produce a single idea or invention which has had a global impact. Needham, famously, sought to 
answer this conundrum and this gave rise to the so-called "Needham Question" which in Mandarin is known as Li Yeuse nanti.

Western fascination-and sometimes fear-of all things Chinese are nothing new. For instance, today, in certain contexts, "China" refers to the finest pottery or what is sometimes called chinaware. This is because for many centuries the finest and most elegant pottery was produced in China and the name has stuck even though it became synonymous with very fine English porcelain.

The Chinese style, in former centuries, was also greatly admired and emulated in advanced western countries such as Great Britain. The $18^{\text {th }}$ century, for instance, witnessed European interest in Chisonere, where western art forms were explicitly informed by a Chinese design ethic. For instance, Britain's King George IV's sumptuous coastal/seaside Palace at Brighton, England has an interior that is in the Chinese style.

The British, too, were impressed and dismayed by Imperial Chinas lengthy and onerous civil service examination which had the objective of selecting only the brightest to work for the imperial court. Today, the highest echelons of Britain's civil service are commonly known as "mandarins".

\section{BRAND CHINA: SOFT POWER}

In nation branding terms, the notion of "soft power"-coined by Professor Joseph Nye of Harvard University - it relevant to our discussion of Brand China. Nye defined soft power as:

"the ability to get what you want through attraction rather than coercion or payments." (The Economist, 2011d).

Curiously, whereas in "hard power" terms, there is no disputing the fact that China, in nation branding terms, has considerable economic and military power-its soft power on the international stage is comparatively feeble. Moreover its cultural brand power (which in this article is defined as "the social, and economic, attractiveness of a country's cultural and intellectual repertoire") is weak: which was not the case in centuries past. Arguably, the Vatican City State's "soft" and "cultural" brand power is more significant. For instance to date, no Chinese citizen has been awarded a Nobel Prize in the sciences or economics.

As a corrective to the above state of affairs the Chinese State has sought variously marshalled Confucius/Confucianism and the writing of Sun Tzu as a means of 
burnishing the soft and cultural power of Brand China. However, this has been with limited success and reference to Sun Tzu's musings on the art of war is, for some, an incongruous use of soft power.

Most notable of these initiatives is the establishment of 300 Confucius Institutes overseas which has the aim of promoting Mandarin. However, for some, the close links of the Confucian Institutes to the Chinese State is problematic. Also, since the time of Chairman Mao, the brand values of Confucianism have been downgraded and denigrated: as such the promotion of Confucianism, at best, seems curious. Tellingly, a landmark statue of Confucius was removed from Tiananmen Square in Peking in 2011 after a short period of time: a decision which is more in keeping with the decades-old narrative of the Chinese State which regards Confucianism is a negative force because of its close its associations with China's imperial, feudal and "backwards" past.

Whereas Confucianism stresses benevolence, righteousness and harmony it seem extraordinary that the Chinese State has sought to promote of Sun Tzu and, moreover, of his magnum opus "The Art of War." This seems to be a highly ill-advised "export" of soft power, since "The Art of War" celebrates the dark side of the human character and commends selfishness and cunning: Chinese values which are not so much enticing but are nauseating (The Economist, 2011d).

\section{WORKSHOPS OF THE WORLD-GREAT BRITAIN AND CHINA: HYBRID COMPANIES AND STATE CAPITALISM}

Today, Chinese companies tend to be either manufacturing or sales-driven. Compared to many western nations, branding (and particularly corporate brandings) remains under developed.

China's recent and rapid industrialisation is similar to which characterised Great Britain during the first industrial revolution: today, China is the workshop of the world just as once Great Britain was (Balmer 2010). As with British companies of the past, manufacturing entities realised that branding their products, services-and indeed the company itself (corporate branding): not only enabled them to connect with their customers but also allowed them to impart their products and services with added meanings and values and, of course, enabled them in many instances to command a higher price (Balmer 2010). Moreover, just as Great Britain pursued "state capitalism" which led to the introduction of hybrid companies in the 17th Century -consider the British East India Company-China is embarking on the same course today. Hybrid companies serve both the state and shareholders. As such, senior managers need to 
juggle the requisites of government along with the provisos of the market, including the share price. This explains why they are called hybrid companies.

\section{SHANZAI (COUNTERFEIT BRANDS) AND BRAND SAVOIR FARE IN CHINA}

Traditionally, China has been known for its prowess in offering counterfeit brands: what in Mandarin as known as Shanzai. Today, counterfeit brands are still prevalent and popular. For example, $30 \%$ of all mobile phones; $80 \%$ of computer software phones are fakes (The Economist, 2012a).

However, one interesting trend within China has been the move away from Shanzai, coupled with an increased appreciation of bona fide (rather than fake) brands but also a behavioural shift (among the middle and upper classes) that well-known (especially luxury brands) are purchased because they denote a mark of quality/excellence and trustworthiness. Also, in China account needs to be taken of the fact that luxury brandsand the premium price paid for them-both connotes and communicates status. Often luxury brands are used as "gift items"- Progressively, the Chinese upper classes are more likely to be mocked if they are spied carrying a fake Gucci handbag (The Economist, 2012a).

The above helps explain why, Chinese tourists on a European tour, invariably include visits to retailer brand stores such as Louis Vuitton, and Hugo Boss. Curiously, the Grand Duchy of Luxembourg is a favoured destination brand not only because of its status as a Sovereign Dukedom and because it can be visited in a morning but also because, as a national brands, it is admired by the Chinese for its national wealth. Consider Chinese students who, typically, devote a third of their holiday budgets to the purchase and, more especially, well-known brands (The Economist, 2010b) are not consumed for reasons of ego.

The Chinese also categorise and prioritise overseas corporate brands differently from their western counterparts. For instance, Chinese tourists prefer Cambridge over Oxford University as a tourist destination and, in particular, seek out a particular willow tree at Kings College, Cambridge. Why? Because, the tree, college and University were immortalised in the poem "On Leaving Cambridge" penned by the celebrated $20^{\text {th }}$ century Chinese poet, Xu Zhimo (The Economist, 2010b).

\section{LITERATURE REVIEW: CORPORATE BRANDS IN CHINA}

A systematic review of the literature pertaining to Chinese brands and brand management in China was undertaken during 2011 and 2014. From this analysis the literature was found to be: small in scale; of recent origin (underdeveloped); empirical 
insights are, comparatively speaking, slight; and most researchers are Chinese or are of Chinese extraction. Moreover, six dominant themes appeared to characterise the Chinese brand canon with the literature focussing on:

1. Chinese brand names and marques

2. Chinese brand loyalty and consumer behaviour

3. Chinese brand and Chinese cultural values

4. Chinese brands stakeholder and communications

5. Chinese brands and international marketing

6. Chinese approaches to luxury brands

These are detailed in greater depth below: See Figure 3 Below which shows the above in visual form whilst table 1 details the main literature relating to the above.

\section{Figure 3 Main Themes In The Literature on Chinese Brands}

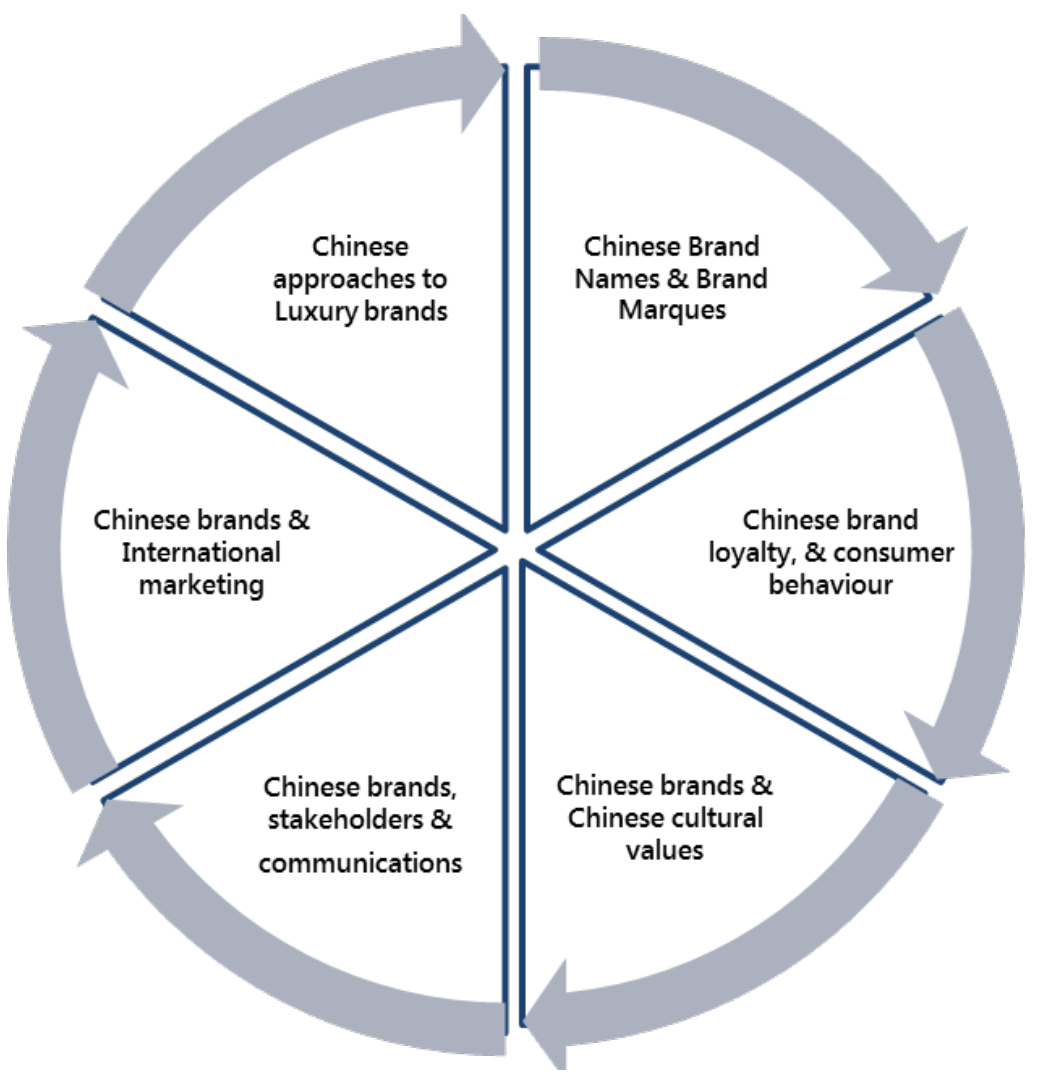


Table 1

\begin{tabular}{|c|c|}
\hline $\begin{array}{l}\text { Chinese brands and } \\
\text { cultural values }\end{array}$ & $\begin{array}{l}\text { Yau (1988); Gilmor (2004); Leonidou et al., (2007); Wang (2007); Ackerman et al } \\
\text { (2009); Atwal and Williams (2009); Hsu et al , (2009); Heslop et al, (2010); Yu and } \\
\text { Bastin (2010); Dynon (2011); Llamas and Belk (2011); Chen (2012); Gao (2012); } \\
\text { Rothschild et al. , (2012); Sun and Paswan (2012); Ashton (2013); Balmer and Chen } \\
\text { (2015); }\end{array}$ \\
\hline $\begin{array}{l}\text { Chinese brand } \\
\text { loyalty and } \\
\text { consumer } \\
\text { behaviour }\end{array}$ & $\begin{array}{l}\text { Zaichkowsky (1999); Jai-Ok, Forsythe, Gu and Moon (2002); Dickson, Lennon, } \\
\text { Montalto, Shen and Zhang (2004); Laroche, et al. (2005); Xu (2002); Sun and Wu } \\
\text { (2004); Bian and Veloutsou (2007); Teng and Laroche (2007); Su (2007); Wang } \\
\text { (2007); Venkatraman and Nelson (2008); Chan (2008); O'Cass and Choy (2008); Ha, } \\
\text { Janda and Park (2009); Uncles, et al (2010); Yu and Bastin (2010); Diamantopoulos } \\
\text { et al., (2011); Sun and Paswan (2011); Laforet and Chen (2012); Usunier and } \\
\text { Sbizzera (2012); Walley and Jiang (2012); Hu, Liu, Wang and Yang (2012); Gao et } \\
\text { al. (2013); Sonmez et al., (2013); }\end{array}$ \\
\hline $\begin{array}{l}\text { Chinese approaches } \\
\text { to luxury brands }\end{array}$ & $\begin{array}{l}\text { Phau and Teah (2009); Kuang-peng, Peng, Hackley and Rungpaka (2011); Ying, } \\
\text { Sun and Song (2011); Xiao Lu and Pras (2011); Zhan and He (2012); Li, Li and } \\
\text { Kambele (2012); Bian and Forsythe (2012); Wang and Song (2013); Zhang and Kim } \\
\text { (2013); }\end{array}$ \\
\hline $\begin{array}{l}\text { Chinese brand } \\
\text { names and Chinese } \\
\text { brand marques. }\end{array}$ & $\begin{array}{l}\text { Schmitt, Pan and Tavassoli (1994); Huang (1997); Dong and Helms (2001);Huang } \\
\text { (2001); Li and Murray (2001); Zhang and Schimitt (2001); Lee and Ang (2003); } \\
\text { Zhang and Schmitt (2004); Kilic, Miller and Vollmers (2009); Kum, Lee, and Qiu } \\
\text { (2011); Schmitt and Zhang (2012); }\end{array}$ \\
\hline $\begin{array}{l}\text { Chinese brands and } \\
\text { International } \\
\text { marketing }\end{array}$ & Kirca et al., (2005); Cui and Jiang (2010); Peng et. al., (2008); Peng et. al., (2009) \\
\hline $\begin{array}{l}\text { Chinese brands } \\
\text { stakeholders and } \\
\text { communications }\end{array}$ & Peng ( 2012); Chen et al (2013); \\
\hline
\end{tabular}

\section{CORPORATE BRAND COMMUNICATION IN CHINA}

Before discussing corporate brand communication in China and the model relating to the aforementioned in the interests of clarity a distinction needs to be made between traditional corporate communications and corporate brand communications. In essence, corporate communications is an area of management/corporate marketing whose theories, models and instrumental insights adopts a corporate-level communications perspective which focusses on stakeholders and, significantly, has an organisation's corporate identity at its core (Illia and Balmer 2012).

Corporate brand communication is similar to the above in many regards with the important proviso that it has a corporate brand at its core (Balmer 2012). It should be noted that the earliest writing on corporate brand management noted the significance of 
corporate communication in the context of corporate brand management (see: Balmer 1995 p.34). Later, Balmer (2001) went on to note the importance of total corporate communications in communicating the corporate brand promise/corporate covenant and stated:

"Corporate brands need to meet the expectations of a whole range of internal and external stakeholders, stakeholder groups and networks, all of whom are crucial to an organisation's success. Reinforcing, and maintaining, awareness of the functional and emotional values of the corporate brand is complicated. A corporate brand is made known, and experienced, through multiple channels of communication. Thus, senior managers, need to focus on total corporate communications rather than on marketing communications." (Balmer 2001 pp. 1-2)

From the authors' scrutiny of the corporate brand literature on China it was noticeable that there was an absence of work on brand communication vis-à-vis Chinese brands and, more specifically, on Chinese corporate brands. It should be noted there is a dearth of writing/insight on corporate brand communications generally within the corporate marketing/brand literature; however see: Balmer (2012). The analysis of the literature on Chinese brands (and taking account the distinct characteristics and societal norms within China) it was evident that a bespoke Chinese corporate brand communication model was efficacious. In developing such a model, the point of departure was the Total Corporate Communications framework of Balmer and Gray (1999).

Apart from its focus on Chinese corporate brands per se, the additional dimensions which need to be factored in are:

- Family Communications: acknowledges the importance of the Chinese extended family even in terms of corporate brand communications and reflects China's firmly-held Confucian ethic

- Gaunxi Communications: acknowledges the particularities as well as the critical importance of the China's distinctive "network" system. Very little can be achieved in China without the support of such networks

- Party Communications: acknowledge the pivotal importance of the Communist Party of China in all manner of decision making in the country. Very little can be achieved in Mainland China without the support of the Party. For instance, the 
Party (analogous to the Government) can determine the ownership structure of organisations and corporate brands (NB: Does not apply to Taiwan).

Table 2 compares the dimensions of Balmer and Gray's (1999) framework and the Chinese corporate brand communications framework detailed here.

\begin{tabular}{|c|c|c|}
\hline Dimensions & $\begin{array}{l}\text { Total Corporate } \\
\text { Communications Framework } \\
\text { (Balmer and Gray 1999) }\end{array}$ & $\begin{array}{l}\text { Chinese Total Corporate Brand } \\
\text { Communications Framework }\end{array}$ \\
\hline $\begin{array}{l}\text { PRIMARY } \\
\text { COMMUNICATIONS }\end{array}$ & $\begin{array}{l}\text { The main modes of } \\
\text { communications is via an } \\
\text { institution's organisation's } \\
\text { corporate identity (which } \\
\text { includes, among others, what an } \\
\text { entity does and how it goes } \\
\text { about its business/purposes and } \\
\text { encompasses, an organisation's } \\
\text { values, culture and purposes; its } \\
\text { products and services; style etc. } \\
\text { Importantly, it also includes } \\
\text { communication discourses of } \\
\text { managers and other } \\
\text { organisational members with } \\
\text { stakeholders). }\end{array}$ & $\begin{array}{l}\text { The main modes of } \\
\text { communications are via an } \\
\text { institution's organisation's } \\
\text { corporate identity which } \\
\text { delivers the corporate brand } \\
\text { covenant/promise. The corporate } \\
\text { brand promise serves as a bi- } \\
\text { lateral, albeit informal contract } \\
\text { between an organisation/s and } \\
\text { stakeholders the DELIVERY of } \\
\text { this informal contract (corporate } \\
\text { brand covenant) is via an } \\
\text { organisation/s corporate identity } \\
\text { (which includes, among others, } \\
\text { what an entity does and how it } \\
\text { goes about its business/purposes } \\
\text { and encompasses, an } \\
\text { organisation's values, culture } \\
\text { and purposes; its products and } \\
\text { services; style etc. Importantly, it } \\
\text { also includes communication } \\
\text { discourses of managers and other } \\
\text { organisational members with } \\
\text { stakeholders). }\end{array}$ \\
\hline $\begin{array}{l}\text { SECONDARY } \\
\text { COMMUNICATIONS }\end{array}$ & $\begin{array}{l}\text { This encompasses formal } \\
\text { corporate communications } \\
\text { centred on corporate identity } \\
\text { attributes and is aimed at } \\
\text { customers and other } \\
\text { internal/external stakeholders } \\
\text { and includes (among others) } \\
\text { corporate advertising, corporate }\end{array}$ & $\begin{array}{l}\text { This encompasses formal } \\
\text { communications centred on the } \\
\text { corporate brand } \\
\text { covenant/corporate brand } \\
\text { promise and is aimed at } \\
\text { customers and other } \\
\text { internal/external groups and } \\
\text { includes (among others) }\end{array}$ \\
\hline
\end{tabular}




\begin{tabular}{|c|c|c|}
\hline & $\begin{array}{l}\text { design, corporate public } \\
\text { relations, ethical corporate } \\
\text { communications) }\end{array}$ & $\begin{array}{l}\text { corporate brand advertising, } \\
\text { corporate brand design, } \\
\text { corporate brand public relations, } \\
\text { ethical corporate brand } \\
\text { communications) }\end{array}$ \\
\hline $\begin{array}{l}\text { TERTIARY } \\
\text { COMMUNICATIONS }\end{array}$ & $\begin{array}{l}\text { This includes "non- } \\
\text { controllable" corporate } \\
\text { communications about the } \\
\text { organisation's corporate identity } \\
\text { by stakeholders and other } \\
\text { groups and encompasses word- } \\
\text { of-mouth communications, } \\
\text { media communication } \\
\text { commentary and spin. } \\
\text { Competitor communication and } \\
\text { spin; social media commentary } \\
\text { and narratives are now also } \\
\text { highly significant. }\end{array}$ & $\begin{array}{l}\text { This includes "non- } \\
\text { controllable" corporate } \\
\text { communications about the } \\
\text { corporate brand by stakeholders } \\
\text { and other groups and } \\
\text { encompasses word-of-mouth } \\
\text { communications, media } \\
\text { communication commentary and } \\
\text { spin. Competitor communication } \\
\text { and spin; social media } \\
\text { commentary and narratives. }\end{array}$ \\
\hline $\begin{array}{l}\text { FAMILY } \\
\text { COMMUNICATIONS }\end{array}$ & $\begin{array}{l}\text { (may in certain instances be } \\
\text { applicable-for instance in family-run } \\
\text { businesses-but was not detailed in } \\
\text { the original framework) }\end{array}$ & $\begin{array}{l}\text { This encompasses bi-lateral } \\
\text { family-focussed } \\
\text { communications about the } \\
\text { corporate brand on the part of } \\
\text { managers, other organisational } \\
\text { members, (and can also include } \\
\text { customers and other } \\
\text { stakeholders). Such an approach } \\
\text { is embedded in Confucian } \\
\text { philosophical precepts. }\end{array}$ \\
\hline $\begin{array}{l}\text { GUANXI } \\
\text { COMMUNICATIONS }\end{array}$ & $\begin{array}{l}\text { Not included in the original } \\
\text { framework (but would be important } \\
\text { in Chinese contexts) }\end{array}$ & $\begin{array}{l}\text { This encompasses bi-lateral } \\
\text { Gaunxi (network-focussed) } \\
\text { communications. Guanxi is an } \\
\text { enduring feature of business } \\
\text { within China and there is a } \\
\text { strong reliance on these } \\
\text { networks of "influential } \\
\text { figures" in order to achieve } \\
\text { organisational and individual } \\
\text { activities. It is grounded in the } \\
\text { premise of the exchange of } \\
\text { favours. } \\
\text { Guanxi comprises three } \\
\text { components: } \\
i \text { : Ganqing-the emotional bond } \\
\text { between Guanxi members } \\
\text { ii: Renqing-favour reciprocity } \\
\text { iii: Xinren-bi lateral trust between } \\
\text { members }\end{array}$ \\
\hline
\end{tabular}




\begin{tabular}{|c|c|c|}
\hline & & $\begin{array}{l}\text { Guanxi communication-among } \\
\text { others-also includes the giving of } \\
\text { presents, invitation to dinners } \\
\text { and socialising. It can, therefore, } \\
\text { be multifaceted owing to the } \\
\text { complex web of relationships } \\
\text { which can impact on the } \\
\text { corporate brand. }\end{array}$ \\
\hline PARTY COMMUNICATIONS & $\begin{array}{l}\text { Not included in the original } \\
\text { framework but would be applicable } \\
\text { in the context of Mainland China. }\end{array}$ & $\begin{array}{l}\text { Communicating with the } \\
\text { Communist Party of China is a } \\
\text { pre-requisite/highly desirable } \\
\text { activity owing to the People's } \\
\text { Republic of China position as a } \\
\text { one-party Marxist state. The } \\
\text { Communist Party is, in effect, a } \\
\text { non-negotiable, KEY } \\
\text { STAKEHOLER and in very } \\
\text { many instances the major } \\
\text { SHAREHOLDER. Without the } \\
\text { imprimatur of the party very little } \\
\text { can be achieved. } \\
\text { (Does not readily apply to Taiwan } \\
\text { and is of lesser importance in Hong } \\
\text { Kong and Macau, although still } \\
\text { important). }\end{array}$ \\
\hline
\end{tabular}

\section{Figure 4 Corporate Brand Communications in China}

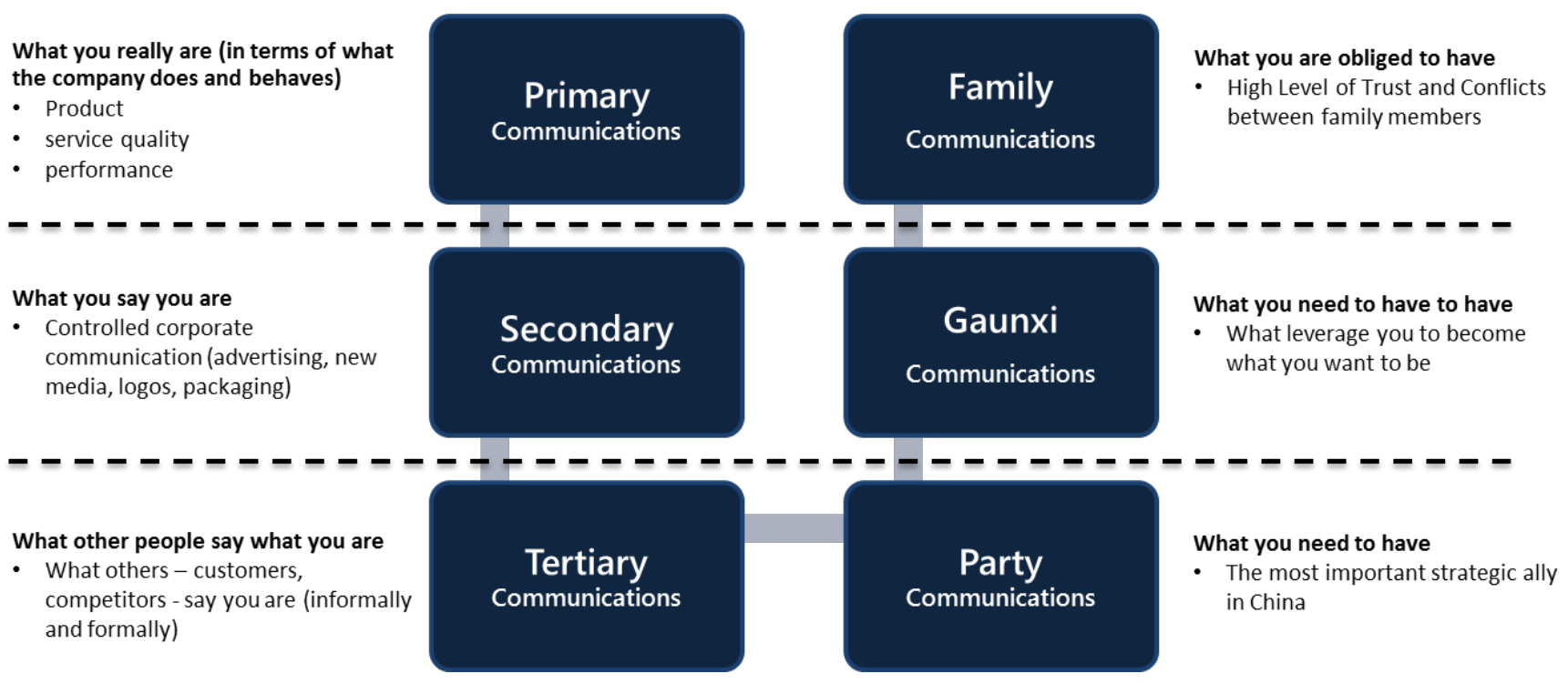




\section{DEVELOPMENT STRATEGIES OF CHINA'S BRANDS}

In this section we provide a summary of our analysis of the various brand development strategies identified by our scrutiny of the activities of Chinese organisations. Six major strategies emerged from our analysis and these are briefly detailed below and are shown in diagrammatic form in Figure 5.

1. Home Grown: China has innumerable brands some of which are known on the global stage such as Huawei.

2. Corporate Heritage: comparatively few indigenous corporate heritage/heritage brands have survived the ravages of the last century and the travails of the Cultural Revolution. There are very few corporate heritage brands having a provenance dating back to the $17^{\text {th }}$ Century. One of these is the Tong Ren Tang traditional Chinese medicine corporate brand.

3. Acquisition: China's love and admiration of overseas brands; the lack of wellestablished home-grown brands and the desire to own global brands and the ability to acquire extant brands is a key feature of China's brand development strategy. Consider the acquisition of the Volvo care brand Geely.

4. Association: one means of burnishing China's indigenous corporate brands - and another brand development strategy-has been to engage in a temporary association with a high-profile overseas corporate brand. Arguably, the most celebrated instance of this is Lenovo's temporary associated with IBM)

5. Joint Venture: this is a very common corporate brand development strategy and this can be found across many business sectors. Consider the joint venture of Shanghai Automotive Industry Corporation and Volkswagen. (e.g. Shanghai Volkswagen)

6. Alliance: this also represents a distinct aspect of China's brand development strategy. It is especially prominent in terms of airline Alliances. Consider Air China and Shenzhen Airlines membership of the Star Alliance; Cathay Pacific's membership of the One World Alliance; China Eastern Airlines, China Southern Airlines and Xiamen Air's membership of the Sky Alliance. 


\section{Figure 5 China's Brand Development Strategy}

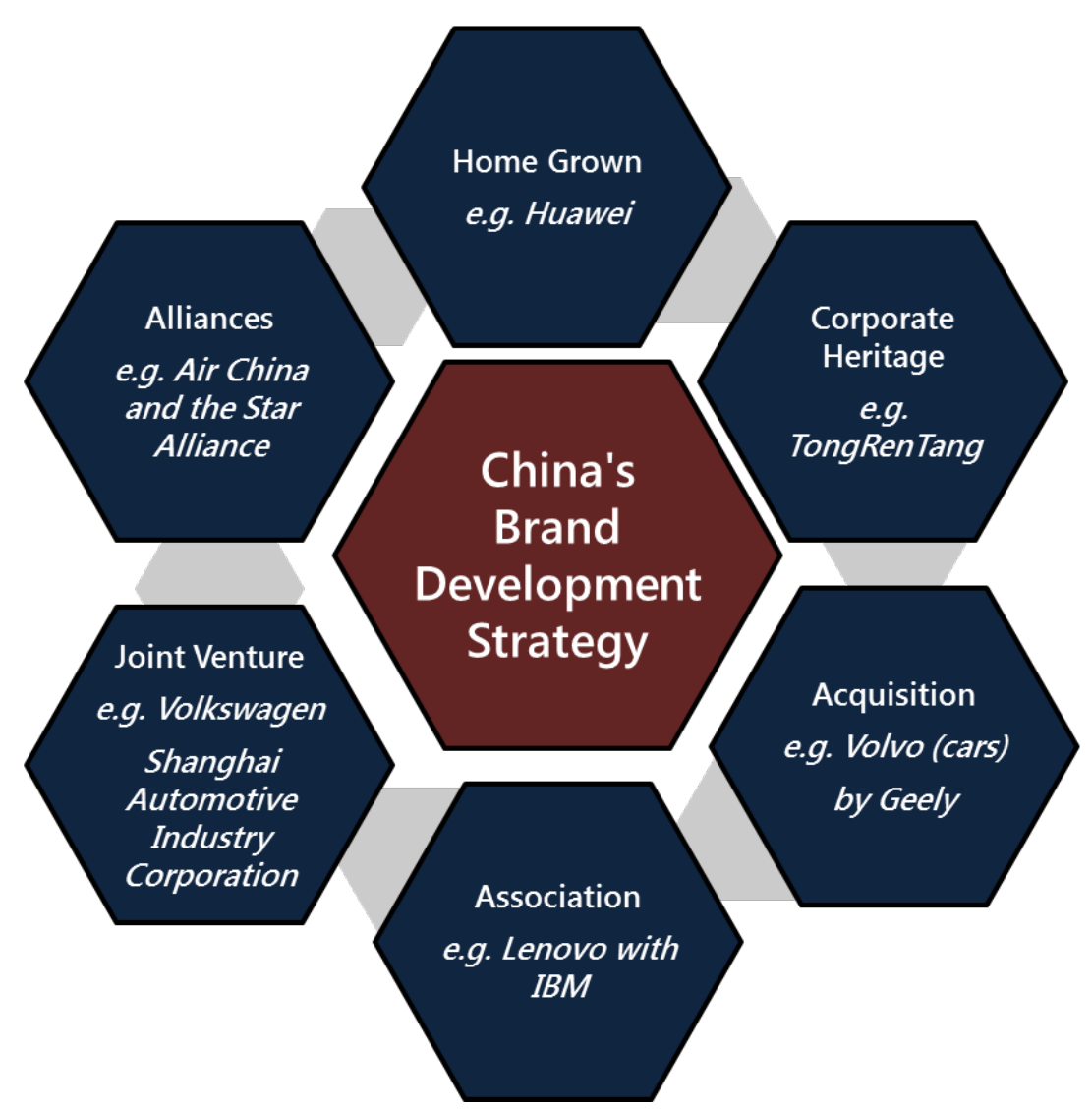

\section{BRANDING IN CHINA: THE FUTURE}

Although it is difficult to precisely predict the future look of the Chinese brand scape there seems little cause to question the exponential growth in and the importance attached to brands - and home grown brands -in China. With an increase in disposable incomes consumers are likely to crave greater brand choice and continue their love of and for western brands and more particularly luxury brands. The acquisition of foreign brands by China also seems likely to continue and this is an attendant part and parcel of China's re-emergence as a major mercantile power. The above being said, the changing mores and habits among the Chinese (for instance a greater predilection for meat and processed foods) and the continuing concern with food quality and food contamination will provide opportunities for even greater numbers of indigenous and foreign brands. China's ageing population also afford numerous brand opportunities as will an increasing literature and technology savvy youth. However, sight must not be lost that China is a very diverse nation and there are considerable differences between its regions and ethnicities thus allowing more niche and local brand to flourish. 


\section{REFLECTION}

Any article on China's brands-owing to the breadth and complexity of the subject area cannot capture every facet of this increasingly important area. However, it is hoped that this article provides some meaningful reflections and insights which, in their totality, it is hoped will be of singular significance. The foremost contributions of this article include are the identification of seven factors which explain the growth of interest in brands in China; the documentation of the main themes contained in canon vis-à-vis China's brands. Of particular significance are the authors' classification of distinct modes of brand development in China and, moreover, the recognition that corporate brand communications in China is qualitatively different from any other country and this has led to the formal introduction of a distinct Chinese corporate brand total communications framework. Finally, mindful that JBM is primarily concerned with brand management the authors have been highly mindful in providing both scholars and practitioners of brand management instrumental insights and perspectives. 


\section{REFERENCES}

Abulaiti, G., Frank, B., Enkawa, T., and Schvaneveldt, S. J. (2011). How Should Foreign Retailers Deal With Chinese Consumers? A Cross-National Comparison of the Formation of Customer Satisfaction. Journal of Marketing Channels, 18(4): 353-373.

Ackerman, D., Hu, J., and Wei, L. (2009). Confucius, cars, and big government: Impact of government involvement in business on consumer perceptions under Confucianism. Journal of Business Ethics, 88(3): 473-482.

Atwal, G., and Williams, A. (2012). Is this Shangri-Laandquest; The case for authenticity in the Chinese and Indian hospitality industry. Journal of Brand Management, 19(5): 405-413

Bian, Q., and Forsythe, S. (2012). Purchase intention for luxury brands: A cross cultural comparison. Journal of Business Research, 65(10): 1443-1451.

Balmer, J.M.T. (1995) Corporate branding and connoisseurship, Journal of General Management, 21(1): 24-42.

Balmer, J.M.T. (2001) The three virtues and seven deadly sins of corporate brand management, Journal of General Management, 27(1): 1-17.

Balmer, JMT. (2010) Explicating corporate brands and their management: Reflections and directions from 1995, Journal of Brand Management, 18(3):180- 196

Balmer, J.M.T. (2012) Corporate Brand Management Imperatives: Custodianship, Credibility, and Calibration, California Management Review, 54(3): 6-33.

Balmer, JMT. (2013) Corporate brand orientation: What is it? What of it? Journal of Brand Management, 20(9):723- 741

Balmer, J.M.T. and Chen. W. (2015) Corporate Heritage Brands in China: Consumer engagement with China's most celebrated corporate heritage brand-Tong Ren Tang: 同仁堂 . Journal of Brand Management (this edition)

Balmer. J.M.T. and Gray, E.R. (1999) Corporate identity and corporate communications: creating a competitive advantage, Corporate Communications: An International Journal. 4(4): 171-176.

Bian, X., and Veloutsou, C. (2007). Consumers' attitudes regarding non-deceptive counterfeit brands in the UK and China. Journal of Brand Management, 14(3): 211-222.

Bigley, G. A., and Pearce, J. L. (1998). Straining for shared meaning in organization science: Problems of trust and distrust. Academy of Management Review, 23(3): 405-421.

Chan, A. K., and Yuan Huang, Y. (1997). Brand naming in China: a linguistic approach. Marketing Intelligence and Planning, 15(5): 227-234.

Chan, A. K., and Huang, Y. Y. (2001). Principles for brand naming in Chinese: the case of drinks. Marketing Intelligence and Planning, 19(5): 309-318.

Chen, N. (2012). Branding national images: The 2008 Beijing Summer Olympics, 2010 Shanghai World Expo, and 2010 Guangzhou Asian Games. Public Relations Review, 38(5): 731-745. 
Chen, W., Woods, A., and Singh, S. (2013). Organisational change and development of reformed Chinese township and village enterprises. Journal of Organizational Change Management, 26(2): 353-369.

Custance, P., Walley, K., and Jiang, D. (2012). Crisis brand management in emerging markets: Insight from the Chinese infant milk powder scandal. Marketing Intelligence and Planning, 30(1): 18-32.

Diamantopoulos, A., Schlegelmilch, B., and Palihawadana, D. (2011). The relationship between country-of-origin image and brand image as drivers of purchase intentions: a test of alternative perspectives. International Marketing Review, 28(5): 508-524.

Dickson, M. A., Lennon, S. J., Montalto, C. P., Shen, D., and Zhang, L. (2004). Chinese consumer market segments for foreign apparel products. Journal of Consumer Marketing, 21(5): 301-317.

Dong, L.C. and Helms, M.M. (2001) Brand name translation model: a case analysis of US brands in China. The Journal of Brand Management 9(2): 99-115

Fan, Y. (2006). The globalisation of Chinese brands. Marketing Intelligence and Planning, 24(4): 365-379.

Frank, B., Abulaiti, G., Herbas Torrico, B., and Enkawa, T. (2013). How do Asia's two most important consumer markets differ? Japanese-Chinese differences in customer satisfaction and its formation. Journal of Business Research, 66(12): 2397-2405.

Gao, T. T., Sultan, F., and Rohm, A. J. (2010). Factors influencing Chinese youth consumers' acceptance of mobile marketing. Journal of Consumer Marketing,27(7): 574-583.

Gilmore, F. (2004). Shanghai: Unleashing creative potential. The Journal of Brand Management, 11(6): 442-448.

Guo, X., Wei Hao, A., and Shang, X. (2011). Consumer perceptions of brand functions: an empirical study in China. Journal of Consumer Marketing, 28(4): 269-279.

Ha, H. Y., Janda, S., and Park, S. K. (2009). Role of satisfaction in an integrative model of brand loyalty: Evidence from China and South Korea. International Marketing Review, 26(2): 198220.

Harry Rothschild, N., Alon, I., and Fetscherin, M. (2012). The importance of historical Tang dynasty for place branding the contemporary city Xi'an. Journal of Management History, 18(1): 96-104.

Heslop, L. A., Nadeau, J., and O'Reilly, N. (2010). China and the Olympics: views of insiders and outsiders. International Marketing Review, 27(4): 404-433.

Hsu, S. Y., Dehuang, N., and Woodside, A. G. (2009). Storytelling research of consumers' selfreports of urban tourism experiences in China. Journal of business research, 62(12): 1223-1254.

Hu, J., Liu, X., Wang, S., and Yang, Z. (2012). The role of brand image congruity in Chinese consumers' brand preference. Journal of Product and Brand Management, 21(1): 26-34.

Hung, K. P., Huiling Chen, A., Peng, N., Hackley, C., Amy Tiwsakul, R., and Chou, C. L. (2011). Antecedents of luxury brand purchase intention. Journal of Product and Brand Management, 20(6): 457-467.

Kilic, O., Miller, D. W., and Vollmers, S. M. (2009). A comparative analysis of Chinese and Japanese company and brand icons. Journal of Asia-Pacific Business, 10(3): 221-237. 
Kirca, A. H., Jayachandran, S., and Bearden, W. O. (2005). Market orientation: a meta-analytic review and assessment of its antecedents and impact on performance. Journal of Marketing, 69(2): 24-41.

Kum, D., Lee, Y. H., and Qiu, C. (2011). Testing to prevent bad translation: Brand name conversions in Chinese-English contexts. Journal of Business Research, 64(6): 594-600.

Laforet, S., and Chen, J. (2012). Chinese and British consumers' evaluation of Chinese and international brands and factors affecting their choice. Journal of World Business, 47(1): 54-63.

Laroche, M., Kalamas, M., and Huang, Q. (2005). Effects of coupons on brand categorization and choice of fast foods in China. Journal of Business Research, 58(5): 674-686.

Leonidou, L. C., Palihawadana, D., and Talias, M. A. (2007). British consumers' evaluations of US versus Chinese goods: A multi-level and multi-cue comparison. European Journal of Marketing, 41(7/8): 786-820.

Li, G., Li, G., and Kambele, Z. (2012). Luxury fashion brand consumers in China: Perceived value, fashion lifestyle, and willingness to pay. Journal of Business Research, 65(10): 1516-1522.

Liaogang, H., Chongyan, G., and Zi'an, L. (2007). Customer-based brand equity and improvement strategy for mobile phone brands: Foreign versus local in the Chinese market. International Management Review, 3(3): 76.

Llamas, R., and Belk, R. (2011). Shangri-La Messing with a Myth. Journal of Macromarketing, 31(3): 257-275.

O'Cass, A., and Choy, E. (2008). Studying Chinese generation Y consumers' involvement in fashion clothing and perceived brand status. Journal of Product and Brand Management, 17(5): 341-352.

Park, S. H., and Luo, Y. (2001). Guanxi and organizational dynamics: Organizational networking in Chinese firms. Strategic Management Journal, 22(5): 455-477.

Peng, M. W., and Luo, Y. (2000). Managerial ties and firm performance in a transition economy: The nature of a micro-macro link. Academy of Management Journal, 43(3): 486-501.

Phau, I., and Teah, M. (2009). Devil wears (counterfeit) Prada: a study of antecedents and outcomes of attitudes towards counterfeits of luxury brands.Journal of Consumer Marketing, 26(1): 15-27

Schmitt, B. H., Pan, Y., and Tavassoli, N. T. (1994). Language and consumer memory: The impact of linguistic differences. Journal of Consumer Research,

Schmitt, B., and Zhang, S. (2012). Selecting the right brand name: An examination of tacit and explicit linguistic knowledge in name translations. Journal of Brand Management, 19(8): 655665.

Sonmez, M., Yang, D., and Fryxell, G. (2013). Interactive Role of Consumer Discrimination and Branding against Counterfeiting: A Study of Multinational Managers' Perception of Global Brands in China. Journal of Business Ethics, 115(1): 195-211.

Sun, Q., and Paswan, A. (2012). Country branding through Olympic Games. Journal of Brand Management, 19(8): 641-654.

Sun, T., and Wu, G. (2004). Consumption patterns of Chinese urban and rural consumers. Journal of Consumer Marketing, 21(4): 245-253. 
Teng, L., and Laroche, M. (2007). Building and testing models of consumer purchase intention in competitive and multicultural environments. Journal of Business Research, 60(3): 260-268.

The Economist (2008a) Doing business in China: April 10.

The Economist (2008b) Business in China: On a roll. June 26,

The Economist (2010a) Japanese manufacturers: Leaving home. November 18

The Economist (2010b) Chinese tourists: A new Grand Tour. December 16.

The Economist (2010c) Remembering the Boxer Uprising: A righteous fist. December 16,

The Economist (2011a) The fashion industry: The glossy posse. October 1,

The Economist (2011b) Food safety in China: In the gutter. October 29.

The Economist (2011c) State capitalism in China: Of emperors and kings. November 12.

The Economist (2011d) Suan Tzu and the art of soft power. December 17: $71-74$

The Economist (2011e) The East India Company: The Company that ruled the waves.

December: 17

The Economist (2012a) Brands in China: Pro logo. January: 14

The Economist (2012b) Urbanising China: A nation of city slickers. January: 21

The Economist (2012c) Credit cards in China: Citi building. February 11

The Economist (2014a) Past and future tense. December 20:15.

The Economist (2014b) The art is red. December 20: 85

The Economist (2015) Gone Shopping p. 73 March: 28

Uncles, M. D., Wang, C., and Kwok, S. (2010). A temporal analysis of behavioural brand loyalty among urban Chinese consumers. Journal of Marketing Management, 26(9-10): 921-942.

Venkatraman, M., and Nelson, T. (2008). From servicescape to consumptionscape: a photoelicitation study of Starbucks in the New China. Journal of International Business Studies, 39(6): 1010-1026.

Winchester, S. (2008) Bomb, Book and Compass: Joseph Needham and the Great Secrets of China, Viking, London.

Xiao Lu, P., and Pras, B. (2011). Profiling mass affluent luxury goods consumers in China: A psychographic approach. Thunderbird International Business Review, 53(4): 435-455.

Yau, O. H. (1988). Chinese cultural values: their dimensions and marketing implications. European Journal of Marketing, 22(5): 44-57.

Yu, C., and Bastin, M. (2010). Hedonic shopping value and impulse buying behavior in transitional economies: A symbiosis in the Mainland China marketplace. Journal of Brand Management, 18(2): 105-114.

Yue-Yuan, Huang. (2001). Chinese brand naming: A linguistic analysis of the brands of ten product categories. The Journal of Product and Brand Management,

Zhan, L., and He, Y. (2012). Understanding luxury consumption in China: consumer perceptions of best-known brands. Journal of Business Research,65(10): 1452-1460.

Zhang, B., and Kim, J. H. (2013). Luxury fashion consumption in China: Factors affecting attitude and purchase intent. Journal of Retailing and Consumer Services, 20(1): 68-79.

Zhang, S., and Schmitt, B. H. (2001). Creating local brands in multilingual international markets. Journal of Marketing Research, 38(3): 313-325. 
Zhang, S., and Schmitt, B. H. (2004). Activating sound and meaning: the role of language proficiency in bilingual consumer environments. Journal of Consumer Research, 31(1): 220-228.

\section{EDITORIAL BOX ONE: MAIN THEMES IN THE LITERATURE ON CHINESE BRAND}

\section{Chinese brand names and Chinese brand marques.}

Many authors focus on this aspect of Chinese brands and this aspect of the canon is reasonably well-developed (see: Chan, 1990, 1997; Schmitt, Pan and Tavassoli, 1994; Huang, 1997; Ang, 1997; Chan and Huang, 2001; Huang, 2001; Dong and Helms, 2001; Zhang and Schimitt, 2001; Lee and Ang, 2003; Zhang and Schimitt, 2004; Kilic et al , 2009; Kum et al 2011).

For instance, Schmitt and Zhang (2012) examined the use of tacit linguistic intuitions and explicit linguistic knowledge for brand name translations from English to Chinese for decision makers of foreign brands in China. Their results of the two studies suggest that brand naming is a process that involves accessing deeply engrained linguistic structures, as well as explicit linguistic knowledge and rules.

Different to Schmitt and Zhang (2012)'s research, Villar et. al (2012) studied the perception and purchase intent of foreign-name brands of adult US and Chinese consumers and found that there were no differences between US and Chinese consumers in attitudes towards foreign products or foreign brand names. Price, taste and packaging design may be more important in determining purchase intent.

Chan $(1990,1997)$ identified that the difference in branding the different products is determined by the semantic field by adopting a linguistic approach in an attempt to investigate Chinese branding rules via a preliminary investigation on Chinese names of foreign brands in Hong Kong.

Finally, the research of Kum et al (2011) investigated bilingual consumers' evaluation of brand name translations from logographic-Chinese to alphabetic-English language systems and shows that consumers who are strong in Chinese and weak in English prefer Pinyin translations across all conditions.

\section{Chinese brand loyalty and consumer behaviour}

Consumer behaviour of brands in China has attacked lots of attention recently (Frank et. al, 2013; Abulaiti et al., 2011; Gao et al., 2010; Sonmez et al, 2013). The research of Laforet and Chen (2012) revealed important insights of Chinese and British consumers 
in terms of their evaluations of Chinese, and international brands, along with the factors affecting their brand choice. More recently, Zhang et al , (2014) studied a sample of 1553 Chinese and 1085 Dutch consumers in the banking and supermarket industries reveals that Chinese consumers in general have higher loyalty intentions than Western consumers.

One interesting strand of research focusses on the attitudes of non-Chinese consumers customers attitudes towards Chinese brands. This literature also incorporates research which takes account of country of origin/ brand image (Laforet and Chen, 2012; Diamantopoulos et al 2011; Janda and Park, 2009).

\section{Chinese brands and cultural values}

The need, indeed efficacy, of taking cognisance of Chinese cultural values vis-à-vis our comprehension of China's brands is another, significant, leit motif within the canon.

According to Confucius Chinese cultural values are largely formed and created from interpersonal relationships and social orientations which is the basic pillar of Chinese life today (Yau, 1988). Guanxi, the interpersonal relationships in China, is deeply embedded in Chinese society and business world today. For Chinese corporations, Guanxi benefits market expansion, competitive positioning of firms, enhancing external operations, and gaining trust and support from strategy allies such as Chinese government (Park and Luo, 2001; Bigley and Pearce, 1998; Peng and Luo, 2000; Xin and Pearce, 1996).

The work of Yu and Bastin (2010) found that traditional Chinese culture has exerted an influence on consumerism/brands. More specifically, the significance of Confucianianism (a key and enduring Chinese philosophy which, traditionally, characterises a good deal of Chinese attitudes, behaviour and relations is another, important, stream of thought. For example the work of Ackerman et al (2009) examined the effects of Confucianism on consumer trust of government involvement with products and company brands.

Chen (2012) studies the international mega events in China such as the 2008 Beijing Summer Olympics, the 2010 Shanghai World Expo, and 2010 Guangzhou Asian Games and revealed that people are likely to associate event images, especially positive ones, with those of China and Chinese government. It provided clues and fertile ground for further research on the relationship between international mega events and national and/or governmental image building, projection and branding. The researchers found that firms doing business in China would benefit from a close association with the government 


\section{Chinese brands stakeholders and communications}

The significance of communication channels and the distinct nature of stakeholders and networks are also of material significance in branding terms. The importance of Chinese government can be clearly identified in their corporate communication strategies. Some researchers (i.e. Cui and Jiang, 2010; Peng et. al, 2008; Peng et. al, 2009) explored the positive and negative roles of these MNEs internationalisation from institution-based view. As Nee et al. (2007) note, China's success is built on the gradual liberalisation of product and labour markets, increasing openness to foreign trade, investment in infrastructure and institutional reforms, such as property reforms and privatisation, which provide individual actors with sufficient security for planning, investing and economic risk taking.

\section{Chinese brands and International marketing}

Internationalisation of Chinese brands represents a very important strand of inquiry. For the main, this literature has primarily focused on internationalisation strategies and market orientation (e.g. Peng, 2012; Kirca et al , 2005; Park and Luo, 2001; Bigley and Pearce, 1998; Peng and Luo, 2000). The above being noted, few studies focus on the Chinese companies international branding strategies.

From 1978 onwards, the internationalisation through outward foreign direct investment (OFDI) has enabled Chinese MNEs to access natural resources and different strategic assets (Barney, 1991) and these include brand names, reputation, and RandD capability. At the early stage of the internationalisation (1978-91): almost all of these Chinese MNEs were large state-owned enterprises (i.e. CITIC, COSCO, CNPC, Sinochem, CNOOC, China Minmetals, and COFCO) which were from monopolized industries, such as financial services, shipping, international trading, and natural resources (UNCTAD, 2006) and operated their international business through Hong Kong. This helps explain why early academic work on marketing and branding issues were undertaken by scholars from Hong Kong in the early 1990s. Hong Kong still remains the as one of major locations for international business today after 1997. Deng Xiaoping's southern tour in 1992 enabled the reforms with more liberalized OFDI policy and the internationalisation steps of Chinese MNEs speeded since then. The "go global" strategy by Chinese government initiated in 1999 and China's entry into the World 
Trade Organization (WTO) at the end of 2001 has also accelerated their internationalisation paces. During this period, especially after 2003, quite a number of successful Chinese MNEs started to appear in the global market in addition to those large Chinese SOEs. For instance, Haier is now a significant player in the US market for consumer electronics; Lenovo has become one of the largest PC manufacture after the acquisition of IBM PC business; Huawei has grown into one of giants in the global telecom equipment market; Geely purchased Volvo in 2010 and is now selling its cars in 19 countries outside China. Many researchers (i.e. Mathew, 2006; Rui and Yip, 2008; Deng, 2009; Peng, 2012) have looked at the internationalisation of these Chinese firms. For instance, more recently based on previous work in this context, Peng (2012) commented that acquisitions are the primary entry mode of Chinese MNEs to access natural resources, world-class brands and to overcome their weakness. However, the literature primarily focusses on strategic assets seeking and technology catch-up. However, there is a lack of research on the international branding strategies of these firms, especially the ownership issues and their international brands management strategy.

Developing international brands for Chinese MNEs has not been straight forward. Competing with well-established multinational companies, the international marketing strategy of Chinese multinational companies (e.g. Lenovo, Huawei, Geely) has focused on lower price, good quality, better customer service, product diversification, and innovation. More recently when entering different developing and developed markets. Chinese MNEs are still "searching the stepping stones in the river" to introduce and develop their brands internationally. Some Chinese MNEs have acquired foreign brands to enter the international market. For instance Lenovo acquired IBM' s personal computer business and introduced the first Chinese computer brand in 2005. Similarly Geely's acquisition of Volvo in 2010 and more recently London Taxi in 2013 have also made Chinese automobile manufacture one of the significant competitors in the international automobile market. Different to brand acquisition, Huawei has been a really successful role model for Chinese MNEs in terms of internationalisation. Although Huawei has received criticisms on IPR and Security issues in the USA, it has been recognised as one of most innovative company in the world ${ }^{1}$ and is "perhaps China's most globally successful company" (McGregor 2012). Certainly its international brand development is truly remarkable. Reflecting the corporate communication in

1 "Innovators honoured in 2010 GTB Awards". Global Telecoms Business. 7 June 2010 
China model, Chinese government has played an important role to support the creation and development of these Chinese international brands.

\section{Chinese approaches to luxury brands}

Research relating to luxury brands has also generated a good deal of interest in the canon (e.g. Zhan and He, 2012; Li, Li and Kambele, 2012; Bian and Forsythe, 2012; Zhang and Kim, 2013; Xiao and Pras, 2011). Over recent years research relating to luxury brands has emerged as a significant stream of inquiry and, in part, this not only reflects the phenomenal growth of the Chinese economy and the rise of a large middle class and significant upper class who purchase luxury brands. An especial aspect of China and of many Chinese is the premium that people place on luxury brands in terms of connoting and communicating their status. Of significance is the work of Zhan and He (2012) examined three psychological traits that make Chinese consumers unique compared to their global peers: value consciousness (VC): susceptibility to normative influence (SNI): and the need for uniqueness (NFU) and concluded that consumers evaluate the best-known brands more favourably as they become more value conscious, indicating that luxury products are not necessarily extravagant purchases in China.

Of significance is the work of Kuang-peng et al , Rungpaka (2011) who showed that conceptualisations of luxury brands as found in the west need to be reappraised in Sino contexts since luxury brands (in Asia) are used to communicate, burnish and confer status.

Importantly, the allure of luxury brands to the Chinese has also - famously - found expression in counterfeit luxury brands. For example, the work of Phau and Teah (2009) examined how social and personality factors influence Chinese consumers' attitudes towards counterfeits of luxury brands in Shanghai.

\section{About the Authors:}

John M.T. Balmer is commonly regarded as the "Father" of the Corporate Brand construct; the corporate brand orientation concept the Corporate Marketing notion; the Corporate Heritage Identity/Corporate Heritage Marketing and Monarchical Marketing concepts. He co-developed the Corporate Heritage field. Took his PhD at Strathclyde University, Scotland in 1996, and within 3 years was elected Professor of Corporate Identity at Bradford University School of Management. He subsequently was conferred the title of Professor of Corporate Brand/Identity Management in the same University in recognition of his seminal scholarship on both territories. In a similar vein, in 2007, he was appointed Professor of Corporate Marketing at Brunel University, London where he is Director of the Centre for Research in Marketing. All three 
Professorial positions are understood to be the first appointments of their kind. Since the early 1990s, he has been a leading proponent of the strategic importance of corporate identity, corporate brands, corporate marketing and corporate heritage. He is known for his seminal articles in these areas which have been published in leading journals such as California Management Review, British Journal of Management, Journal of Business Research, European Journal of Marketing, Journal of Business Ethics, Long Range Planning, Journal of Marketing Management, Journal of General Management, and International Studies of Management and Organization. . Since the early 1990s, he has served as a guest editor/joint guest editor of around 20 special editions of academic journals. He is the founder, chairman, and conference organiser of both the International Corporate Identity Group -ICIG- which was established in 1994 and the International Symposium on Corporate Heritage, History and Nostalgia (established in 2001). . He is the Chairman of Board of Senior Consultant Editors of the Journal of Brand Management.

Weifeng Chen is a lecturer at Brunel University Business School London where he specialises in international business/marketing and is a leading member of the school's Centre for Research in Marketing. He has a particular research interest in China and the management of Chinese brands. Dr Chen is a member of the China-Britain Business Council (CBBC). More broadly, his research focusses on marketing strategies in developing markets. His work has been published in the Journal of Organizational Change Management, Regional Studies, International Journal of Production Economics, Journal of Information System Management, Advances in Information Systems Management, International Journal of Knowledge Management Studies etc 